\title{
Detection of Hepatitis E Virus in the Pig Livers and Retail Pork Samples Collected in Selected Cities in China
}

\author{
Jiahui Wang,, Nan Li, ${ }^{1}$ Hongyuan Zhang, ${ }^{1}$ Fengqin Li, ${ }^{1}$ Séamus Fanning, ${ }^{1,2}$ and Tao Jiang ${ }^{1}$
}

\begin{abstract}
Hepatitis E virus (HEV) is a biological hazard that must be controlled and is a recognized etiological agent in viral hepatitis. This is a zoonotic virus and can be transmitted through the fecal-oral route. The pig is an important reservoir host of $\mathrm{HEV}$, and is a source of contamination for the consumer after the consumption of raw or undercooked pork products. When detected, the most prevalent genotype of HEV in China is genotype 4 (denoted as HEV-4). To ensure the safety of this food of animal origin, we undertook a survey of HEV contamination in pig livers and pork samples available for sale, in retail outlets in selected cities in China. Viral RNA was purified from samples collected by lysing in Trizol followed by purification using trichloromethane and virus RNA extract kit. An additional step was applied to improve the recovery rate by adding RNase OUT when extracting virus RNA from pig livers, and the RNA productions were washed in 75\% (v/v) ethanol to remove inhibitors. In total, 158 pig livers and 80 pork samples were procured and analyzed by reverse transcription-quantitative polymerase chain reaction (RT-qPCR). After purification of total RNA from all samples taken and analyzed by RT-qPCR, a single pig liver was positive by this method for HEV. The positive rate was calculated as $0.63 \%$. In this study, a single positive sample was detected. Considering the dietary habits of Chinese people, pork is a popular food that on occasion may be contaminated with HEV, thereby posing a threat to consumer health. Ongoing surveillance is required to assess the risk to human health arising from HEV-contaminated pork being offered for sale, at retail outlets, especially in the areas of China where pig production is practiced.
\end{abstract}

Keywords: hepatitis E virus, RNA extraction, real-time RT-qPCR

\section{Introduction}

$\mathbf{H}$ EPATITIS E VIRUS (HEV) is one of many important agents that cause acute viral hepatitis in humans. This viral infection is linked to 20 million clinical cases annually, with 56,000 HEV deaths globally (Blasco-Perrin et al., 2016). HEV is a member of the Hepeviridae family and contains a single-stranded positive sense RNA genome, which is $\sim 7.2 \mathrm{kbp}$ in size. The viral genome consists of three open reading frames (ORFs), in which ORF1 encodes nonstructural proteins, ORF2 encodes the capsid protein, and ORF3 encodes a viroprotein like protein (Himmelsbach et al., 2018). Eight genotypes have been identified and are denoted as HEV-1-HEV-8. Of these, HEV-1, HEV-2, HEV-3, HEV-4, and $\mathrm{HEV}-7$ are reported to infect humans. HEV-3 and HEV-4 are zoonotic genotypes, which could infect both human and other animals, such as pigs, wild boar, and deer (Tei et al., 2003; Lee et al., 2016; Woo et al., 2016). In some African countries, due to poor hygiene conditions, HEV is transmitted primarily through water, with HEV-1 and HEV-2 being the prevalent genotypes (Smith et al., 2016). In contrast, in European countries, HEV-3 is identified as the main genotype, and in India and China, the prevalent genotype is recorded to be HEV-4 (Kamar et al., 2012).

$\mathrm{HEV}$ is an important foodborne virus and it can be transmitted through the fecal-oral route. Pigs are natural hosts for $\mathrm{HEV}$, the virus could be detected in the small intestines, lymph nodes, colons, and livers in the swine model (Williams et al., 2001). Previous studies reported that humans can be infected by HEV after the consumption of food of animal origin (Schielke et al., 2011). Several lines of evidence suggest that HEV can be transmitted through consumption of contaminated pork and wild boar meat, particularly meat derived from the livers of these animals (Colson et al., 2010). In China, serological data indicated that the positive rate of the HEV antibody measured in pig blood was $83.6 \%$ (Wang et al., 2002). Similarly Li et al. (2019) reported HEV nucleic acid in swine feces, with a positive detection rate of $61.4 \%$.

\footnotetext{
${ }^{1}$ Key Laboratory of Food Safety Risk Assessment, National Health Commission of the People's Republic of China, China National Center for Food Safety Risk Assessment (CFSA), Beijing, People's Republic of China.

${ }^{2}$ UCD-Centre for Food Safety, School of Public Health, Physiotherapy \& Sports Science, University College Dublin, Dublin, Ireland.
} 
Other authors also reported high positive rates of detection of RNA in pig feces (Zhou et al., 2019).

Given the lack of standardized and reliable virus extraction methodologies from food matrices including pork and pig liver, there is limited data describing HEV prevalence in contaminated pig livers and pork samples for sale to consumers at retail outlets in China. In this study, we report on the development of an optimized extraction method designed to aid the isolation and subsequent detection of HEV from pork and pig livers. The latter assay was then deployed to provide new information on the prevalence of HEV contamination in pig livers and pork samples for sale in retail markets in three selected cities in China.

\section{Materials and Methods}

\section{Pork and pig livers sampling}

Some 158 pig livers and 80 pork samples were randomly purchased and collected from local retail markets in Yancheng, Hangzhou, Wenling, Taizhou, and Liaoyuan, in September 2018. The samples were from different retailers, but there were no details about the farms from where the samples were collected. The samples collected were stored at $-20^{\circ} \mathrm{C}$ before being transported to the China National Center for Food Safety Risk Assessment (CFSA) laboratory on ice.

\section{HEV nucleic acid purification from the pig livers and pork}

A $1 \mathrm{~g}$ sample of pig liver or $5 \mathrm{~g}$ pork was thawed slowly at room temperature, and then combined together with a volume of $7 \mathrm{~mL}$ TRIZOL (15596018; Life Technology), $10 \mu \mathrm{L}$ $1.0 \times 10^{10} \mathrm{PFU} / \mathrm{L}$ bacteriophage $\mathrm{MS}_{2}$ (LR73141; Longrun Bio-tech), the process control, and $2 \mu \mathrm{L}$ RNase OUT (10777019; Invitrogen). All were thoroughly stomached in a blender bag by using Stomach Machine BagMixer400CC (024230400S; Interscience). After homogenizing at the six strokes per second velocity for $6 \mathrm{~min}$, the supernatant was removed into a clean sterile tube, and centrifuged again at $1000 \times g$ for $10 \mathrm{~min}$ at $4^{\circ} \mathrm{C}$. Finally, the supernatant was transferred into a new tube and mixed with $5 \mathrm{~mL}$ of $99 \%(\mathrm{v} / \mathrm{v})$ trichloromethane. The mixture was then centrifuged at $17,000 \times g$ for $15 \mathrm{~min}$ at $4^{\circ} \mathrm{C}$, and $140 \mu \mathrm{L}$ of the aqueous portion, recovered carefully by pipette, was transferred into a new tube for viral RNA purification. Viral RNA extraction was performed using a QIAmp Viral RNA Kit(52904; Qiagen) according to the manufacturer's instructions. The mentioned procedure we used was derived from the method reported before (Szabo et al., 2015). We also did the experiment if the PCR inhibitor was too much to affect the results. Purified RNA was separated into two groups: one group was amplified directly and another group was washed and treated by using $75 \%(\mathrm{v} / \mathrm{v})$ ethanol.

\section{Amplification controls}

Highly purified nuclease-free water was used as the blank control. Phosphate-buffered saline $(0.01 \mathrm{~mol} / \mathrm{L}, \mathrm{pH} 7.2)$ was used as the negative process control and was run through all stages of the analytical process. A HEV positive sample from pig feces, prepared previously that was maintained by our laboratory, was included as the test positive control. A volume of $10 \mu \mathrm{L} \mathrm{MS}_{2}$ was added into the sample before the RNA extraction as the process control. The purified HEV RNA, which was from the pig's fecal sample, was used as amplification control for reverse transcription-quantitative polymerase chain reaction (RT-qPCR).

\section{Real-time RT-qPCR amplification}

Oligonucleotide primers and detection probes employed in this study were designed to detect HEV. These were commercially synthetized by ThermoFisher Scientific Co. according to the method described by Li et al. (forward primer: 5'-GGT GGT TTC TGG GGT GAC-3', reverse primer: AGG GGT TGG TTG GAT GAA, probe: FAMTGA TTC TCA GCC CTT CGC-MGB) (Li et al., 2019). The real-time RT-qPCR assay to detect the HEV was carried out using RNA Ultrasense One-step Quantitative RT-qPCR System (Invitrogen). Purified RNA was screened by RTqPCR, performed on a CFX96 (BIO-RAD) real-time PCR platform. A final reaction volume of $50 \mu \mathrm{L}$ in each well was composed of $10 \mu \mathrm{L}$ purified nucleic acid template or control and $40 \mu \mathrm{L} \mathrm{HEV} \mathrm{reaction} \mathrm{premix,} \mathrm{containing} 1.25 \mu \mathrm{L}$ of forward primer; $2.25 \mu \mathrm{L}$ of reverse primer, $0.625 \mu \mathrm{L}$ of detection probe, and $19.875 \mu \mathrm{L} \mathrm{ddH}_{2} \mathrm{O}$, along with $25 \mu \mathrm{L}$ $2 \times$ premix buffer and $1 \mu \mathrm{L}$ enzyme mix according to the manufacturer (Invitrogen, USA).

The thermal profile comprised $50^{\circ} \mathrm{C}$ for $30 \mathrm{~min}$ and $95^{\circ} \mathrm{C}$ for $5 \mathrm{~min}$, followed by 45 cycles of $95^{\circ} \mathrm{C}$ for $15 \mathrm{~s}, 60^{\circ} \mathrm{C}$ for $30 \mathrm{~s}$, and $65^{\circ} \mathrm{C}$ for $30 \mathrm{~s}$.

The $\mathrm{MS}_{2}$ as process control was amplified according to the $\mathrm{MS}_{2}$ Process Control Real Time RT-PCR Kit Instructions (Longrun Bio-Tech Company, China). Details are as follows: a final reaction volume of $25 \mu \mathrm{L}$ in each well was composed of $5 \mu \mathrm{L}$ nucleic acid template together with $17.5 \mu \mathrm{L}$ premix buffer and $2.5 \mu \mathrm{L}$ enzyme mix. The thermal profile comprised $42^{\circ} \mathrm{C}$ for $30 \mathrm{~min}$ and $95^{\circ} \mathrm{C}$ for $5 \mathrm{~min}$, followed by 45 cycles of $95^{\circ} \mathrm{C}$ for $15 \mathrm{~s}, 60^{\circ} \mathrm{C}$ for $30 \mathrm{~s}$, and $65^{\circ} \mathrm{C}$ for $30 \mathrm{~s}$.

\section{Results}

As a background to detection strategies employed, a sample would be determined as being positive when the $\mathrm{Ct}$ values obtained after RT-qPCR were $<35 \mathrm{U}$. The $\mathrm{Ct}$ values of the negative and blank controls were higher than 40 , respectively, whereas the positive control $\mathrm{Ct}$ value was $<35$. The sample should be reassayed if the $\mathrm{Ct}$ value was between 35 and 40. The sample was determined as negative if the $\mathrm{Ct}$ value of the sample was $>40$. Besides, the recovery rate of $\mathrm{MS}_{2}$ was $>1 \%$ and the amplification inhibition index was $<2$. (The amplification inhibition index is the $\mathrm{Ct}$ value of the undiluted sample RNA + control RNA minus $\mathrm{Ct}$ value of the water + control RNA.)

\section{Process control}

The process control $\mathrm{MS}_{2}$ was recovered from all samples and the recovery rate ranged from $1.27 \%$ to $100 \%$. All of the sample RNA amplification inhibition indexes were $<2$. The $\mathrm{Ct}$ values of the positive control were $<35$ and the $\mathrm{Ct}$ values of the blank control and negative control were $>40$. The standard curve of $\mathrm{MS}_{2}$ is shown in Figure 1, the effective rate of amplification was determined to be $96.4 \%$, with a slope of -3.412. All of these results indicated that the experimental data obtained were valid. 

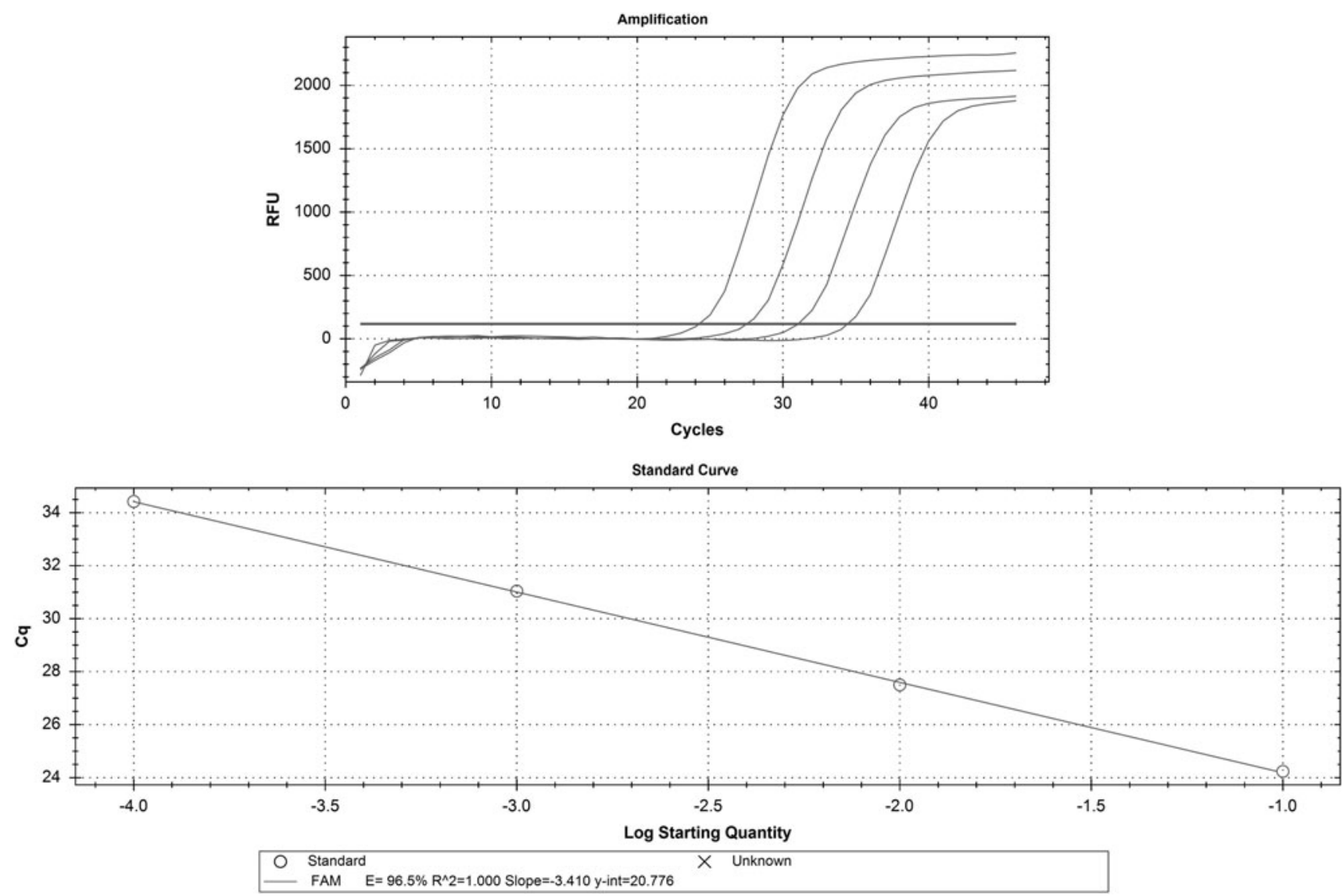

FIG. 1. Standard curve of $\mathrm{MS}_{2}$.

The comparison result of whether used or not the RNase OUT

The recovery rate of $\mathrm{MS}_{2}$ of the group without adding RNase OUT was $<1 \%$, whereas it is $>1 \%$ of the group adding RNase OUT. Results are given in Table 1.

\section{The efficiency of the method used to remove} the PCR inhibitor

The amplification inhibition indexes of the group treated by using $75 \%(\mathrm{v} / \mathrm{v})$ ethanol are $<2$, whereas those of the untreated group were $>2$, which means the $75 \%$ (v/v) ethanol could remove some of the PCR inhibitors to make sure the results are available. Results of the method used to remove the PCR inhibitor are given in Table 2.

Table 1. The Comparison Result of Whether USED OR NOT THE RNASE OUT

\begin{tabular}{lcc}
\hline Method name & $\begin{array}{c}\text { Recovery } \\
\text { rate }(\%)\end{array}$ & $\begin{array}{c}\text { Average recovery } \\
\text { rate (\%) }\end{array}$ \\
\hline Not add RNase OUT & 0.24 & 0.21 \\
& 0.27 & \\
Add $2 \mu \mathrm{L}$ RNase OUT & 0.13 & 1.79 \\
& 1.64 & \\
& 2.13 & \\
& 1.59 & \\
\hline
\end{tabular}

Contamination of HEV in pig livers and the pork from retail market

The standard curve of HEV is shown in Figure 2, the effective rate of amplification was determined to be $103.6 \%$, with a slope of -3.238 . A total of 158 pig livers and 80 pork samples were collected from five cities located in three provinces in China. In total, 158 pig livers were tested and only 1 sample was positive, giving a calculated HEV positive

TABle 2. Influence of the Amplification INHIBITION INDEXES WHEN APPLYING 75\% (v/v) Ethanol to TrEat the RNA Extraction

\begin{tabular}{lccc}
\hline Method name & $\begin{array}{c}\text { Ct } \\
\text { value }\end{array}$ & $\begin{array}{c}\text { Average } \\
\text { Ct value }\end{array}$ & $\begin{array}{c}\text { Amplification } \\
\text { inhibition } \\
\text { indexes }\end{array}$ \\
\hline No treatment & 33.61 & 33.19 & 9.74 \\
No treatment & 33.19 & & \\
No treatment & 32.76 & & \\
$75 \%$ Ethanol treated & 26.33 & 25.28 & 1.83 \\
$75 \%$ Ethanol treated & 25.19 & & \\
$75 \%$ Ethanol treated & 25.21 & & \\
Water control & 23.66 & 23.45 & \\
Water control & 23.59 & & \\
Water control & 23.09 & & \\
\hline
\end{tabular}

The amplification inhibition indexes were calculated by RNA extraction $\mathrm{Ct}$ value minus the water $\mathrm{Ct}$ value, the result is available when the value is $<2$. 

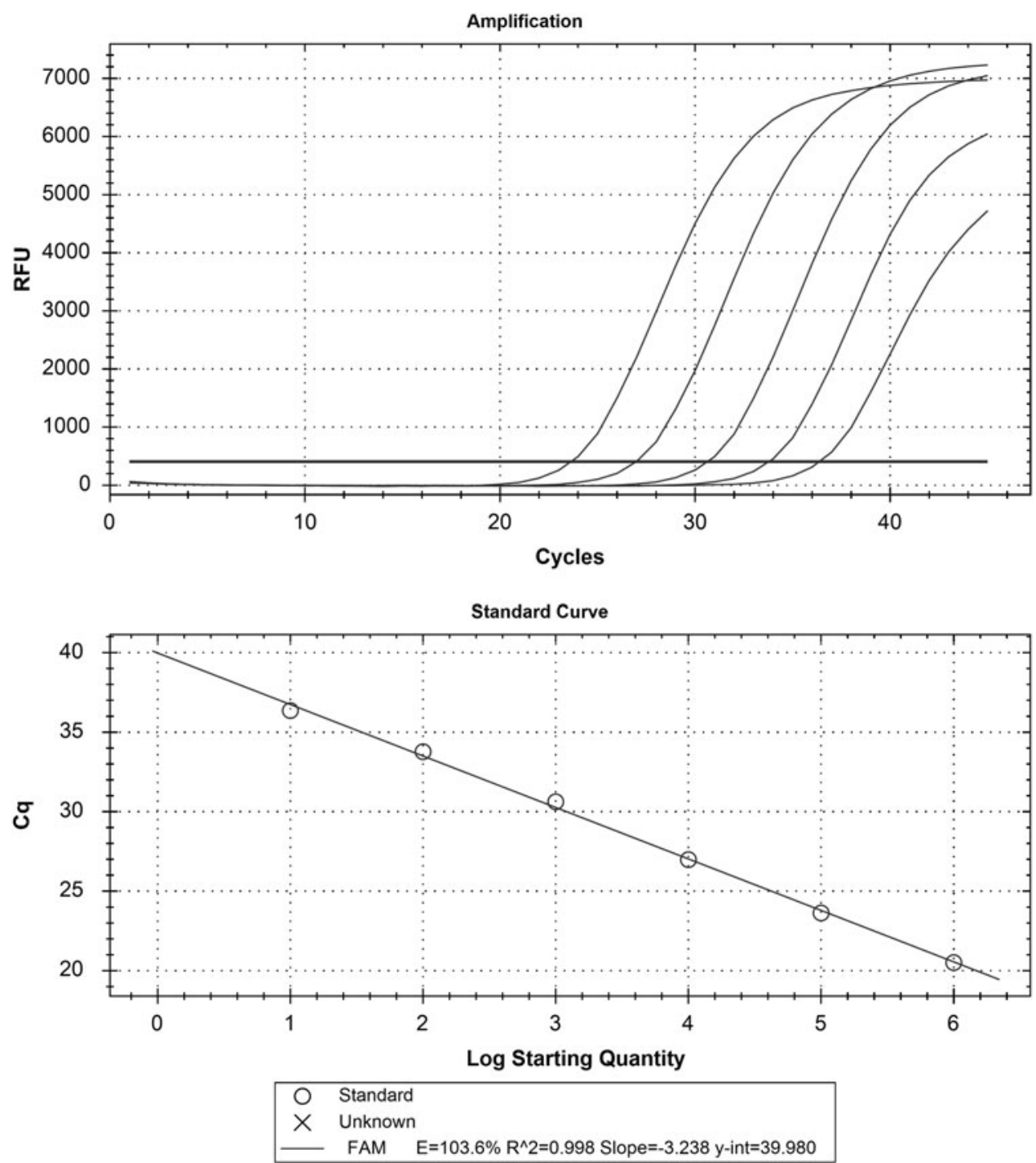

FIG. 2. Standard curve of HEV. HEV, hepatitis E virus.

rate for pig livers of $0.63 \%$. Among the 80 pork samples tested, none of these tested positive for HEV.

Results are given in Table 3 and Figure 3, and the fluorescence amplification curve of the positive sample is shown in Figure 4.

\section{Discussion}

HEV is a zoonotic virus, which can infect susceptible individuals after the consumption of raw or semicooked pork.
Based on recent seroprevalence and very recent blood donor data, it is likely that there are at least two million locally acquired HEV infections in Europe every year (Dalton et al., 2018). Seroprevalence studies of humans suggested that even one-third of the world's population will be infected at some point during their lifetime (Webb et al., 2019). Food products containing raw pork liver are suspected to be vehicles for transmission of HEV (Pavio et al., 2014). Researchers from Korea collected 100 pig livers from a local grocery market, the positive rate of HEV was $3 \%$, all of them belonged to

Table 3. Result of Hepatitis E Virus Contamination in Pork and Pig Livers

\begin{tabular}{|c|c|c|c|c|c|c|}
\hline \multirow[b]{2}{*}{ City } & \multicolumn{3}{|c|}{ Pig livers } & \multicolumn{3}{|c|}{ Pork } \\
\hline & No. of pig livers & Positive number & Positive rate & No. of pig pork samples & Positive number & Positive rate \\
\hline Yancheng & 32 & 1 & $3.13 \%$ & 20 & 0 & 0 \\
\hline Hangzhou & 34 & 0 & 0 & 20 & 0 & 0 \\
\hline Wenling & 32 & 0 & 0 & 20 & 0 & 0 \\
\hline Taizhou & 30 & 0 & 0 & 20 & 0 & 0 \\
\hline Liaoyuan & 30 & 0 & 0 & 0 & 0 & 0 \\
\hline Total & 158 & 1 & $0.63 \%$ & 80 & 0 & 0 \\
\hline
\end{tabular}




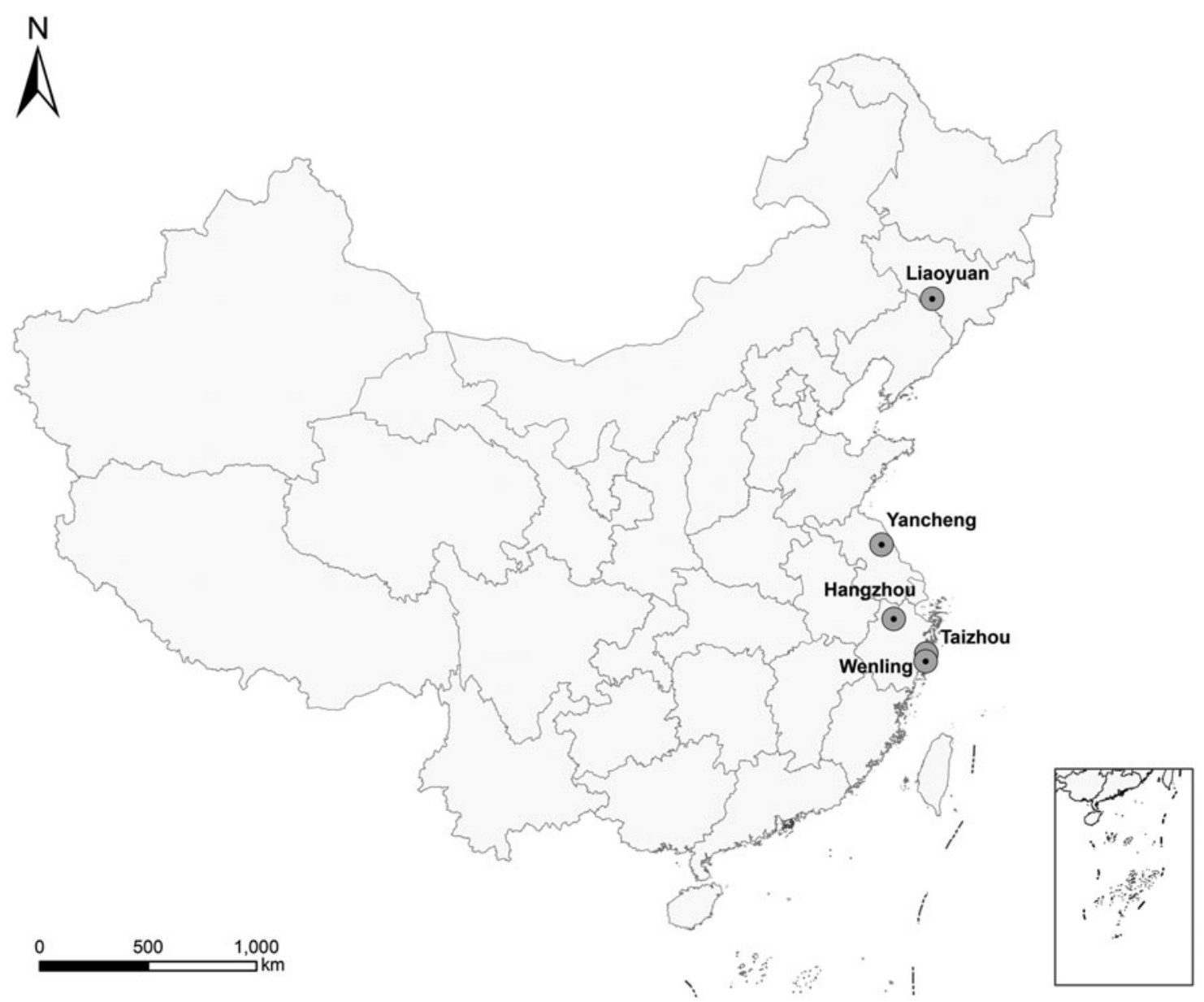

FIG. 3. The sampling place in China.

HEV-4 (Go et al., 2019). Similar research carried out in Italy showed that the positive rates of HEV-3 in the raw and dry liver sausage were $22.2 \%$ and $4.3 \%$, respectively (Di Bartolo et al., 2015). In some areas of China, such as in Tibet and Yunnan provinces, consumption of pig livers without cook- ing is common, thereby exposing the consumer to infection. As the components of these food matrices, such as pig liver, are complex, such inhibiting components contained therein may interfere with test reactions, and the lack of reliable virus extraction method from foods is a direct result.

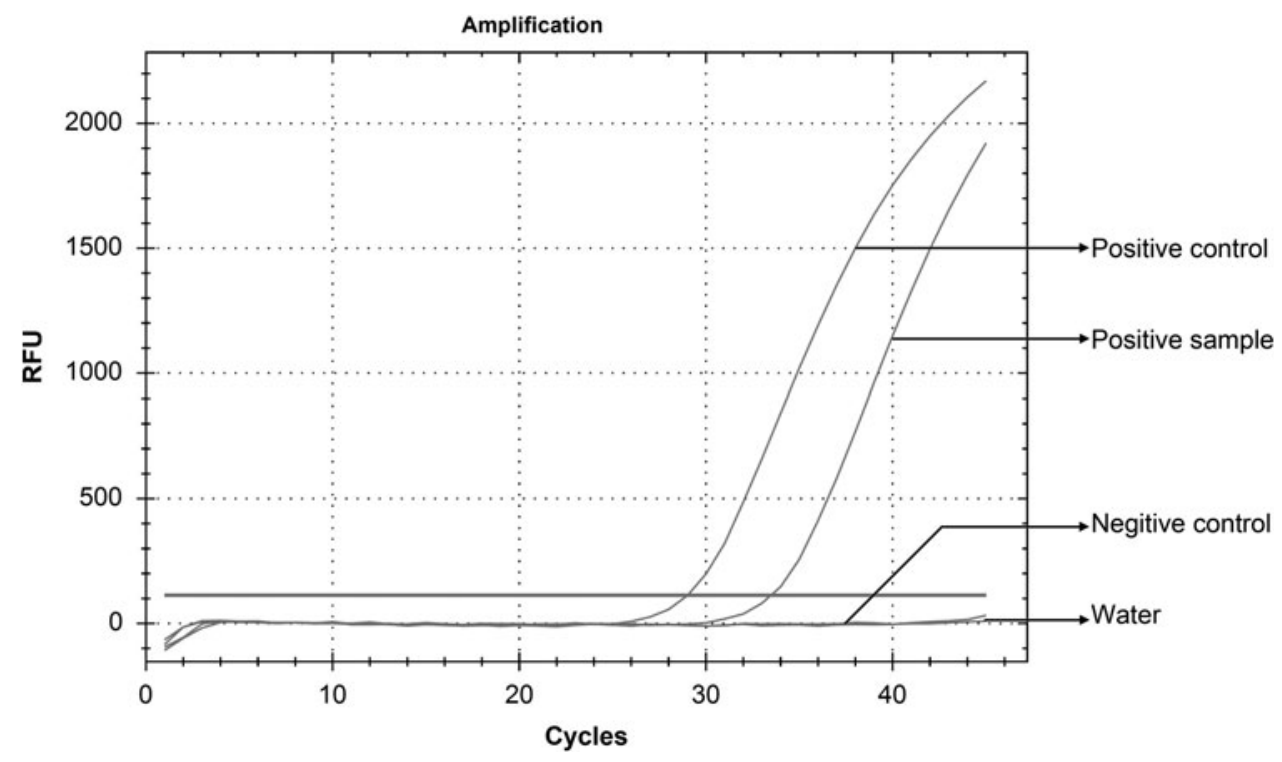

FIG. 4. The HEV positive result of pig liver. HEV, hepatitis E virus. 
Previously, Szabo reported on the development of a method to detect HEV in a pork sample, and when HEV was detected in pig liver sausages, the viral recovery rate was $<1 \%$. This suggests that the concentration of PCR inhibitors in the purified viral RNA was too high to ensure the success of this PR-based assay (Szabo et al., 2015).

In this study, we optimized the original method of Szabo. The sample size and the dose of RNase OUT used in RNA extraction were optimized, and $75 \%(\mathrm{v} / \mathrm{v})$ ethanol was used to remove PCR inhibitor from the purified RNA, a step that improved the method recovery rate and the amplification efficiency. $\mathrm{MS}_{2}$ was used as process control being added to the sample to monitor the virus extraction efficiency. Also we introduced an amplification control during the PCR amplification to assess the amplification inhibition indexes. All of these minimize the false negative and ensure the experimental data are valid. But since some components in the pig liver, such as protoheme and polysaccharide (Qingqing et al., 2014), would interfere with the PCR results, the detection limitation would be affected, so further research should be carried out to increase the sensitivity of the experiment.

The method was subsequently applied in an investigation of HEV contamination in pork and pig livers in selected cities in China. Previously it has been reported that HEV could infect humans after consumption of uncooked meat or livers taken from wild boars in Europe. In China there was no similar evidence that people could be infected with HEV through eating pork and pig livers. But a serological survey of humans in China indicated that the seroepidemiology of $\mathrm{HEV}$ among the rural population was $38 \%$, and the incidence of HEV was 2.8 of 10,000 , most of these being identified as HEV-4 (Zhu et al., 2014). The molecular epidemiology of HEV strains isolated and studied from pigs confirmed the most prevalence genotype to be $\mathrm{HEV}-4$, the same genotype was found in HEV patients (Zhou et al., 2019). This observation suggests that susceptible individuals may become infected with HEV from eating foods of porcine origin, such as pig livers. A recent study showed that the HEV was completely disinfected when the food was cooked with the internal temperature reaching $71^{\circ} \mathrm{C}$ for $20 \mathrm{~min}$ (Barnaud et al., 2012). HEV in pig livers may remain infectious after cooking, a feature that is associated with Chinese cooking methods. Therefore, it is risky for consumers in some areas to eat raw or half cooked pig livers, especially pregnant women.

In our study, the positive rate of pig livers is less than that in the earlier research in Hong Kong, which is $1.5 \%$ (Chan et al., 2017). The different methods of virus extraction that are used in the two studies and the different areas of the sample collection may induce different results. The sensitivity of the method may still need to be improved to detect lower concentration of HEV in samples. Further research is needed to surveil the HEV contamination of the foods in the retail market especially the areas where the human HEV positive rate was high.

\section{Conclusions}

In this study, we optimized the extraction method of HEV in pig livers and pork and applied it to survey HEV in pig livers and pork from the retail market. One positive pig liver sample was detected. It may cause potential harm to consumers' dietary health, considering Chinese eating habits.
The surveillance to HEV contamination in foods should be strengthened, especially in the areas where the human HEV positive rate was high.

\section{Disclosure Statement}

No competing financial interests exist.

\section{Funding Information}

This study was supported by the National Key R\&D Program of China (2018YFC1602501) (the National Key Research and Development Program of China, the Ministry of Science and Technology of China).

\section{References}

Barnaud E, Rogée S, Garry P, Rose N, Pavio N. Thermal inactivation of infectious hepatitis $E$ virus in experimentally contaminated food. Appl Environ Microbiol 2012;78:5153-5159.

Blasco-Perrin H, Abravanel F, Blasco-Baque V, Péron JM. Hepatitis E, the neglected one. Liver Int 2016;36:130-134.

Chan MCW, Kwok K, Hung TN, Chan PKS. Molecular epidemiology and strain comparison between Hepatitis E viruses in human sera and pig livers during 2014 to 2016 in Hong Kong. J Clin Microbiol 2017;55:1408-1415.

Colson P, Borentain P, Queyriaux B, Kaba M, Moal V, Gallian P, Heyries L, Raoult D, Gerolami R. Pig liver sausage as a source of hepatitis $\mathrm{E}$ virus transmission to humans. J Infect Dis 2010;202:825-834.

Dalton HR, Kamar N, Baylis SA, Moradpour D, Wedemeyer H, Negro F. EASL Clinical Practice Guidelines on hepatitis E virus infection. J Hepatol 2018;68:1256-1271.

Di Bartolo I, Angeloni G, Ponterio E, Ostanello F, Ruggeri FM. Detection of hepatitis $\mathrm{E}$ virus in pork liver sausages. Int $\mathbf{J}$ Food Microbiol 2015;193:29-33.

Go HJ, Park BJ, Ahn HS, Lyoo EL, Kim DH, Lee JB, Park SY, Song CS, Lee SW, Choi IS. Identification of hepatitis E virus in bovine and porcine raw livers. J Microbiol Biotechnol 2019;29:2022-2025.

Himmelsbach K, Bender D, Hildt E. Life cycle and morphogenesis of the hepatitis E virus. Emerg Microbes Infect 2018; 7:196.

Kamar N, Bendall R, Legrand-Abravanel F, Xia NS, Ijaz S, Izopet J, Dalton HR. Hepatitis E. Lancet 2012;379:2477-2488. Lee GH, Tan BH, Teo EC, Lim SG, Dan YY, Wee A, Aw PP, Zhu Y, Hibberd ML, Tan CK. Chronic infection with camelid hepatitis $\mathrm{E}$ virus in a liver transplant recipient who regularly consumes camel meat and milk. Gastroenterology 2016;150: 355-357.

Li Y, Jiang T, Li F, Peng Z, Wang J, Li N, Zhang H, Zhang L. Establishment of a method with real-time reverse transcription-polymerase chain reaction for hepatitis $\mathrm{E}$ virus in swine feces and its molecular epidemiology. Wei Sheng Yan Jiu 2019;48:545-559. [In Chinese.]

Pavio N, Merbah T, Thébault A. Frequent hepatitis E virus contamination in food containing raw pork liver, France. Emerg Infect Dis 2014;20:1925-1927.

Qingqing H, Yuxuan L, Shixia H, Lili M, Hongdu M, Daixin H. Research progress on PCR inhibitors in the biological material and their treatment technology. Chin J Forensic Med 2014;29:243-246. [In Chinese.]

Schielke A, Filter M, Appel B, Johne R. Thermal stability of hepatitis e virus assessed by a molecular biological approach. Virol J 2011;8:487. 
Smith DB, Simmonds P, Izopet J, Oliveira-Filho EF, Purdy MA. Proposed reference sequences for hepatitis e virus subtypes. J Gen Virol 2016;97:537-542.

Szabo K, Trojnar E, Anheyer-Behmenburg H, Binder A, Schotte U, Ellerbroek L, Klein G, Johne R. Detection of hepatitis E virus RNA in raw sausages and liver sausages from retail in Germany using an optimized method. Int $\mathrm{J}$ Food Microbiol 2015;215:149-156.

Tei S, Kitajima N, Takahashi K, Mishiro S. Zoonotic transmission of hepatitis $\mathrm{E}$ virus from deer to human beings. Lancet 2003;362:371-373.

Wang YCH, Zhang HY, Cui P, Lan HY, Li SHW, Tian KG, Wang J, Ge SHX, Gu WJ, Wang JX. The prevelance of HEV among pigs and cattle. Chine Prev Med 2002;3:199-201. [In Chinese.]

Webb GW, Dalton HR. Hepatitis E: An underestimated emerging threat. Ther Adv Infect Dis 2019;6:2049936119837162.

Williams TPE, Kasorndorkbua C, Halbur PG, Haqshenas G, Guenette DK, Toth TE, Meng XJ. Evidence of extrahepatic sites of replication of the hepatitis E virus in a Swine Model. J Clin Microbiol 2001;39:3040-3046.

Woo PC, Lau SK, Teng JL, Cao KY, Wernery U, Schountz T, Chiu TH, Tsang AK, Wong PC, Wong EY. New Hepatitis E virus genotype in bactrian camels, Xinjiang, China, 2013. Emerg Infect Dis 2016;22:2219-2221.

Zhou K, Zhou Q, Yang D, Yue H, Tang C, Zhang B. Hepatitis E virus in Tibetan pigs on the Qinghai-Tibetan Plateau: Detection, molecular characterization and infection of BALB/c mice. Arch Virol 2019;164:2943-2951

Zhu FC, Huang SJ, Wu T, Zhang XF, Wang ZZ, Ai X, Yan Q, Yang CL, Cai JP, Jiang HM. Epidemiology of zoonotic hepatitis E: A community-based surveillance study in a rural population in China. PLoS One 2014;9:e87154.

Address correspondence to: Tao Jiang, $M S$

Key Laboratory of Food Safety Risk Assessment National Health Commission of the People's Republic of China China National Center for Food Safety Risk Assessment (CFSA) Panjiayuan Nanli No. 7, Chaoyang District

Beijing 100021

People's Republic of China

E-mail: jiangtao001@cfsa.net.cn 